Рассохина Анна Александровна

аспирант кафедры уголовного права и криминологии Кубанского государственного университета

\section{ПЕНАЛИЗАЦИЯ ВЗЯТОЧНИЧЕСТВА И ДИФФЕРЕНЦИАЦИЯ ОТВЕТСТВЕННОСТИ ЗА НЕГО В УГОЛОВНОМ ЗАКОНОДАТЕЛЬСТВЕ СОВЕТСКОГО ПЕРИОДА}

\section{Аннотация:}

В статье осуществлен анализ подходов к установлению уголовной ответственности за взяточничество в советский период развития Российского государства. Научная новизна заключается в том, что данное исследование является одним из немногих, в котором основное внимание уделяется вопросам пенализации и дифференциации уголовной ответственности. Рассматривается судебная практика данного исторического периода, приведены соответствующие статистические данные. Отмечается, что борьба со взяточничеством велась в течение всего периода существования Советского государства. Изучено содержание действовавших в обозначенный период нормативных правовых актов. Прослеживается эволюционный путь развития подходов в уголовном законодательстве к дифференциации ответственности за взяточничество и его пенализации. Сделан вывод, что многие из положений советского права в измененном и дополненном виде нашли свое отражение в действующем Уголовном кодексе Российской Федерации. Выявлены особенности пенализации и дифференциации уголовной ответственности за взяточничество в советский период, установлены причины неэффективности борьбы с коррупционными преступлениями на данном историческом этапе развития.

Ключевые слова:

коррупция, взяточничество, уголовная ответственность, пенализация, дифференциация уголовной ответственности, коррупционные преступления, советский период.
Rassokhina Anna Aleksandrovna

PhD student, Department of Criminal Law and Criminology, Kuban State University

PENALIZATION OF BRIBERY AND DIFFERENTIATION OF

LIABILITY FOR IT

IN THE SOVIET CRIMINAL LAW

Summary:

The paper analyzes the approaches to establishing criminal liability for bribery during the Soviet period of the Russian state. The novelty lies in the fact that this research is one of the few studies that focuses on penalization and differentiation of criminal liability. The judicial practice of this historical period is analyzed, and the relevant statistics are presented. The author notes the anti-bribery activity conducted throughout the entire Soviet state. Laws and regulations being in force in the above-mentioned period are discussed. The paper identifies the evolving approaches to differentiation of liability for bribery and its penalization in criminal law. It is concluded that many provisions of the amended Soviet law are reflected in the current Criminal Code of the Russian Federation. The paper reveals the aspects of penalization and differentiation of criminal liability for bribery in the Soviet period and determines the reasons for the ineffective fight against corruption offences at this historical stage.

Победой Октябрьской революции 1917 г. был положен конец Российской империи, на ее территории юридически возникло новое государство - Российская Социалистическая Федеративная Советская Республика (РСФСР). Становление новых государственности и правопорядка требовало значительного количества чиновников, обеспечивающих их фрункционирование. Вместе с тем должностные лица являются основными получателями взяток, что свойственно любому государству.

Советским государством была провозглашена решительная борьба со взяточничеством. В.И. Ленин выделял это явление в числе трех основных угроз для существования страны. В связи с этим в 1918 г. он направил в ЦК партии требование об исключении из ее рядов тех членов, которые, являясь судьями по делу о взяточниках, при доказанной, а также признанной взятке приговорили виновных лиц к низшему сроку в полгода тюрьмы. Вместо расстрела взяточников были вынесены такие издевательски мягкие приговоры. В.И. Ленин считал этот поступок позорным для коммуниста [1, с. 31]. И уже 8 мая 1918 г. был издан первый нормативный акт, направленный на борьбу с коррупционными преступлениями, а именно декрет СНК РСФСР «О взяточничестве» [2], подписанный В.И. Лениным собственноручно.

Статьей 1 декрета была установлена уголовная ответственность для лиц, которые состояли на государственной или же общественной службе и были признаны виновными в получении взятки. Предусмотренное нормативным актом наказание составляло не менее пяти лет лишения 
свободы, при этом оно сочеталось с принудительными работами на тот же срок. В названном документе решался вопрос дифференциации ответственности за данное преступление. В качестве квалифицирующего признака предусматривалось совершение преступления лицом, относящимся к имущему классу, который при этом использовал взятку в целях сохранения либо же приобретения привилегий, связанных с правом собственности. В этом случае виновный подлежал наказанию в виде наиболее тяжелых и неприятных принудительных работ, все его имущество подлежало конфискации.

Как отмечено ранее, санкция нормы предусматривала только низший предел уголовного наказания, не определяя при этом высшего. Из-за этого достаточно часто революционные трибуналы осуждали виновных в получении взятки лиц как к длительным срокам лишения свободы, так и к расстрелу.

21 октября 1919 г. был опубликован декрет «О борьбе со спекуляцией, хищениями в государственных складах, подлогами и другими злоупотреблениями по должности в хозяйственных и распорядительных органах» [3]. В соответствии с этим нормативным актом все дела о взяточничестве передавались в Особый революционный трибунал при Всероссийской чрезвычайной комиссии.

Однако принятие названных декретов не способствовало сокращению фактов взяточничества. Это было обусловлено в том числе состоянием экономики во время Гражданской войны. В частности, милиционерам в поселках и деревнях перестали платить заработную плату, что привело к увеличению масштабов взяточничества. Судьи в свою очередь имели возможность налагать штрафы.

После окончания Гражданской войны было принято решение о введении новой экономической политики. Государством стала проводиться работа по кодификации норм права. 16 августа 1921 г. СНК РСФСР был принят декрет «О борьбе со взяточничеством» [4], установивший ответственность как для взяткодателей, так и для взяткополучателей.

Можно сделать вывод, что принятые декреты, регламентировавшие ответственность за взяточничество, основывались на классовом принципе ответственности. Истоком такого подхода являлось мнение о том, что основной причиной данного явления выступали некие сохранившиеся буржуазные элементы. Он не может считаться верным, так как носит идеологический характер и не учитывает факторы, реально провоцирующие взяточничество. Осознание этого обстоятельства подвигло властные органы на установление ответственности за данное преступление для всех чиновников, независимо от того, к какому классу они относятся.

Указанные положения в дальнейшем нашли свое отражение в Уголовном кодексе РСФСР 1922 г. [5]. Согласно его установлениям, взятка могла быть дана не только за выполнение (т. е. за действие), но и за невыполнение определенного действия (т. е. за бездействие) по службе. Наказание при этом, по сравнению с первыми декретами, было сокращено и предусматривало лишение свободы на срок до 5 лет с конфискацией имущества либо без нее. Но при наличии отягчающих обстоятельств срок наказания не мог быть ниже 3 лет. Кроме того, к виновнику могла быть применена высшая мера наказания с конфискацией имущества.

Следует заметить, что названный Кодекс содержал весьма разработанную систему положений о должностных преступлениях. В примечании к ст. 105 уже приводилось определение должностного лица. Однако в ст. 114 УК РСФСР, закрепляющей ответственность за получение взятки, в качестве субъекта преступления было названо не только должностное лицо, но и лицо, состоявшее на государственной, союзной, а также общественной работе [6, с. 8].

Что касается подходов к дифференциации ответственности, то квалифицирующих признаков устанавливалось четыре, а именно: ответственное положение должностного лица; нанесение или же возможное нанесение противоправным деянием ущерба государству; неоднократность получения взятки или же наличие судимости за данное преступление; вымогательство взятки.

Вместе с тем установление весьма суровых наказаний (вплоть до смертной казни) не способствовало укреплению законности в соответствующей сфере.

По оценке А.А. Герцензона, если принять взяточничество в 1922 г. за 100 \%, то в 1923 г. этот показатель составлял 114 \%, 1924 - 153, 1925 - 158 и лишь в 1926 г. упал до 115 \% [7, с. 31].

Новый Уголовный кодекс РСФСР был принят в 1926 г. [8]. В нем впервые в отечественном праве содержалось положение о том, что субъектом получения взятки может являться исключительно должностное лицо.

Говоря о дифференциации ответственности, необходимо отметить, что отягчающих обстоятельств стало три, а именно: ответственное положение лица, которое получило взятку; наличие судимости за это же преступление или неоднократность получения взятки; вымогательство. Таким образом, квалифицированный состав стал исключительно формальным по законодательной конструкции.

Что касается подходов к пенализации, то по части первой (получение взятки без отягчающих обстоятельств) наказание было даже немного сокращено и выражалось в лишении свободы 
на срок до двух лет. За получение взятки при наличии отягчающих обстоятельств лицо подлежало лишению свободы на срок от двух лет с возможным повышением наказания (в зависимости от тяжести деяния) вплоть до расстрела с конфискацией имущества. Но уже с ноября 1927 г. расстрел за получение взятки был отменен.

Новеллой в этом кодексе было положение о том, что лицо, виновное в получении взятки, ни при каких условиях не могло быть освобождено от уголовной ответственности за преступление.

В период установления тоталитарного государства в 1930-е гг. коррупция официально исчезла как общественное явление. Вместе с тем преступления, связанные со взяточничеством, совершались. Подтверждением тому выступают приказы Народного комиссариата юстиции РСФСР от 5 января и 29 апреля 1937 г. «О судебной практике по делам о должностных преступлениях» [9], запрещавшие судам осуждать за должностные злоупотребления рядовых рабочих и колхозников. Именно с этого нормативного акта начинается период отхода от расширительного толкования в определении понятия должностного лица.

Весьма широкое распространение взяточничество получает в период Великой Отечественной войны и после ее окончания. Пленум Верховного суда СССР в 1949 г. принял постановление, в котором были отмечены упущения в деятельности судов, указывалось на недостаточную решимость в борьбе с этим правонарушением и назначение излишне мягких наказаний за его совершение.

Для реализации необходимости совершенствования уголовного законодательства и приведения его в соответствие с изменившимися реалиями общественной жизни 27 октября 1960 г. был принят новый Уголовный кодекс РСФСР [10]. Из его текста следовало, что, по мнению государства, получение взятки представляет собой наиболее серьезный вид коррупционного преступления.

При этом отношение к данному преступлению осталось неизменным. Статья УК РСФСР была практически нерабочей, а статистика не отражала объективную ситуацию, которая сложилась в стране в рассматриваемый период. Следует сказать, что существенных дополнений в содержание рассматриваемой нормы УК РСФСР 1960 г. в первоначальной редакции не вносил, в последующем статья 173 была подвергнута неоднократным изменениям, которые касались вопросов наказания и дифференциации ответственности. Согласно ч. 1 первоначальной редакции ст. 173 УК РСФСР, получение взятки должностным лицом лично или через посредников за выполнение или невыполнение определенного действия наказывалось лишением свободы на срок до 5 лет. Однако в редакции, существовавшей накануне принятия УК РФ 1996 г., санкция ч. 1 ст. 173 предусматривала уже лишение свободы на срок до 10 лет с конфискацией имущества. В первоначальной редакции ч. 2 ст. 173 УКРСФСР получение взятки должностным лицом, занимавшим ответственное положение, или ранее имевшим судимость по данной статье, или вымогавшим взятку, наказывалось лишением свободы на срок от 5 до 10 лет. В последней редакции (в соответствии с Законом РФ от 18 февраля 1993 г. [11]) часть 2 стала предусматривать ответственность за данное деяние, совершенное группой лиц, или неоднократно, или в крупном размере, и содержала в санкции наказание в виде лишения свободы на срок от 5 до 15 лет с конфискацией имущества. Часть 3, в которую в соответствии с Указом Президиума Верховного Совета РСФСР от 28 мая 1986 г. «О внесении изменений и дополнений в некоторые законодательные акты РСФСР» [12] трансформировалась бывшая часть 2, устанавливала ответственность за получение взятки должностным лицом, занимавшим ответственное положение, или ранее судившимся за взяточничество, или получившим взятку в особо крупном размере, и предусматривала наказание в виде лишения свободы на срок от 8 до 15 лет с конфискацией имущества.

Отмеченные изменения способствовали более детальной дифференциации уголовной ответственности за данное преступление в зависимости от степени общественной опасности, что свидетельствовало о желании законодателя ориентироваться на практическую реализацию принципа справедливости при назначении наказания. Все это видится неким элементом демократизации общества.

Таким образом, эволюция санкций за получение взятки в советский период свидетельствует об ужесточении подходов к пенализации этого деяния: если в УК РСФСР 1926 г. за него устанавливалось не менее 2 лет лишения свободы с конфискацией имущества, то УК РСФСР предусматривал ответственность вплоть до 15 лет лишения свободы с конфискацией имущества. Более того, до 1991 г. в случае если получателем взятки являлось должностное лицо, занимавшее ответственное положение, либо взятка была в особо крупном размере, подобное деяние каралось исключительной мерой наказания - смертной казнью. Такое усиление уголовной ответственности за получение взятки было осуществлено Указом Президиума Верховного Совета СССР от 20 февраля 1962 г. «Об усилении уголовной ответственности за взяточничество» [13].

Подобное ужесточение уголовной ответственности было обусловлено ослаблением государственной власти и усилением коррупционных структур. Исследователи того времени отме- 
чают, что в коррупционных делах были замешаны как чиновники, так и работники правоохранительных и судебных органов, ввиду чего смертная казнь за получение взятки была вновь введена в 1962 г. [14, с. 29].

Тем не менее, несмотря на столь жесткие санкции, масштабы взяточничества были весьма значительными.

Следует заметить, что до начала 1980-х гг. тема взяточничества открыто не поднималась. Это явление представлялось как некий пережиток буржуазного общества, чуждый социалистическому строю, а его вредоносность явно недооценивалась [15]. Первым громким коррупционным делом советского периода ученые-исследователи называют дело фрирмы «Океан». Из него было выделено Сочинско-Краснодарское дело, одним из обвиняемых по которому проходил первый секретарь Краснодарского крайкома КПСС, член ЦК КПСС С. Медунов. С приходом к власти Ю. Андропова в 1983 г. борьба с должностными злоупотреблениями активизировалась. В частности, по делу Моспродторга был расстрелян директор Елисеевского гастронома Ю. Соколов [16, с. 25].

Итак, можно констатировать, что борьба со взяточничеством велась в течение всего периода существования Советского государства, в уголовном законодательстве эволюционировали подходы к дифференциации ответственности за это преступление и его пенализации. В основном они нашли отражение и в действующем УК РФ.

\section{Ссылки:}

1. Гладких В.И. Коррупция в России: генезис, детерминанты и пути преодоления // Российский следователь. 2001. № 3. C. 31-36.

2. О взяточничестве : декрет СНК РСФСР от 8 мая 1918 г. // Собрание узаконений и распоряжений правительства за 1917-1918 гг. Управление делами Совнаркома СССР. М., 1942. С. 487.

3. О борьбе со спекуляцией, хищениями в государственных складах, подлогами и другими злоупотреблениями по должности в хозяйственных и распорядительных органах : декрет СНК РСФСР от 21 окт. 1919 г. // Собрание узаконений и распоряжений правительства за 1919 г. Управление делами Совнаркома СССР. М., 1943. С. 727.

4. О борьбе со взяточничеством : декрет СНК РСФСР от 16 авг. 1921 г. // СУ РСФСР. 1921. № 60. Ст. 421.

5. О введении в действие Уголовного кодекса РСФСР : постановление ВЦИК от 1 июня 1922 г. // Там же. 1922 . № 15. Ст. 153.

6. Эстрин А.А. Взяточничество и уголовная репрессия // Еженедельник советской юстиции. 1922. № 39-40. С. 8.

7. История советского уголовного права / А.А. Герцензон, Ш.С. Грингауз и др. М., 1948. С. 131.

8. О введении в действие Уголовного кодекса РСФСР редакции 1926 г. : постановление ВЦИК от 22 нояб. 1926 г. // СУ РСФСР. 1926. № 80. Ст. 600.

9. О судебной практике по делам о должностных преступлениях : приказ НКю РСФСР от 5 янв. 1937 г. // Советская юстиция. 1937. № 6.

10. Уголовный кодекс РСФСР 1960 г. [Электронный ресурс] : утв. Верховным Советом РСФСР 27 окт. 1960 г. Доступ из справ.-правовой системы «КонсультантПлюс».

11. О внесении изменений в Уголовный кодекс РСФСР, Уголовно-процессуальный кодекс РСФСР, Исправительно-трудовой кодекс РСФСР и Закон РСФСР «О милиции» : закон Российской Федерации от 18 февр. 1993 г. № 4510-1// Ведомости СНД РФ и ВС РФ. 1993. № 10. Ст. 360.

12. О внесении изменений и дополнений в некоторые законодательные акты РСФСР : Указ Президиума Верховного Совета РСФСР от 28 мая 1986 г. // Ведомости Верховного Совета РСФСР. 1986. № 23. Ст. 638.

13. Об усилении уголовной ответственности за взяточничество : Указ Президиума Верховного Совета СССР от 20 февр. 1962 г. // Там же. 1962. № 8. Ст. 85.

14. Клепицкий И.А., Резанов В.И. Получение взятки в уголовном праве России. Комментарий законодательства. М., 2001. C. 29.

15. См.: Клим А.М.: 1) Взяточничество: криминологическая характеристика и предупреждение : автореф. дис. ... канд. юрид. наук. Минск, 2013. С. 7 ; 2) История уголовной ответственности за взяточничество // Вопросы криминологии, криминалистики и судебной экспертизы : сб. науч. тр. / ред. А.В. Дулов. Минск, 2009. Вып. 1 (26). С. $43-53$.

16. Крюкова Н.И. Возникновение и история развития коррупции в России // Государственная власть и местное самоуправление. 2013. № 12. С. 25-30.

\section{References:}

'Case Law on Malfeasance: an Order of the People's Commissariat of Justice of the RSFSR as of January 05, 1937' 1937, Sovetskaya yustitsiya, no. 6, (in Russian).

Estrin, AA 1922, 'Bribery and criminal repression', Yezhenedel'nik sovetskoy yustitsii, no. 39-40, p. 8, (in Russian).

Gertsenzon, AA \& Gringauz, ShS (et al.) 1948, History of the Soviet criminal law, Moscow, p. 131, (in Russian).

Gladkikh, VI 2001, 'Corruption in Russia: genesis, determinants and ways to overcome', Rossiyskiy sledovatel', no. 3, pp. 3136, (in Russian).

Klepitsky, IA \& Rezanov, VI 2001, Bribery in the criminal law of Russia. Comment on law, Moscow, p. 29, (in Russian).

Klim, AM 2013, Bribery: forensic characteristics and warning, PhD thesis abstract, Minsk, p. 7, (in Russian).

Klim, AM \& Dulov, AV (ed.) 2009, 'History of criminal liability for bribery', Voprosy kriminologii, kriminalistiki i sudebnoy ekspertizy: sb. nauch. tr., Minsk, iss. 1 (26), pp. 43-53, (in Russian).

Kryukova, NI 2013, 'Background to the development of corruption in Russia', Gosudarstvennaya vlast' $i$ mestnoye samoupravleniye, no. 12, pp. 25-30, (in Russian).

'On Bribery: the Decree of the Council of People's Commissars of the RSFSR as of May 08, 1918' 1942, Sobraniye uzakoneniy i rasporyazheniy pravitel'stva za 1917-1918 gg. Upravleniye delami Sovnarkoma SSSR, Moscow, p. 487, (in Russian).

'On the Fight against Backdoor Sales, Embezzlement in State Warehouses, Forgery and Other Abuses of Power in Economic and Administrative Bodies: the Decree of the Council of People's Commissars of the RSFSR as of October 21, 1919' 1943, Sobraniye uzakoneniy i rasporyazheniy pravitel'stva za 1919 g. Upravleniye delami Sovnarkoma SSSR, Moscow, p. 727, (in Russian). 